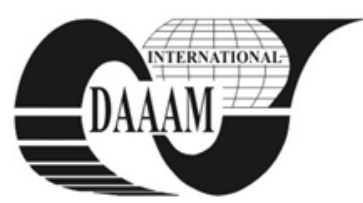

Annals of DAAAM for 2011 \& Proceedings of the 22nd International DAAAM Symposium, Volume 22, No. 1, ISSN 1726-9679 ISBN 978-3-901509-83-4, Editor B. Katalinic, Published by DAAAM International, Vienna, Austria, EU, 2011 Make Harmony between Technology and Nature, and Your Mind will Fly Free as a Bird

\title{
THE INFLUENCE OF INTERNATIONAL STANDARD ISO 9001 IMPLEMENTATION ON THE HUMAN RESOURCE MANAGEMENT IN HOTELS
}

\author{
DRAGICEVIC, M[arija] \& LETUNIC, S[tijepo]
}

\begin{abstract}
The aim of this paper is to research the influence of Quality Managing System ISO 9001 on the human resource management in the hotel businees practice. For the purpose of the paper it has been made desk research and the empirical research. The primary research has been carried out using method of structural interview. In the research we have included all the hotels in Croatia which have implemented Standard ISO 9001. The experience of hotels in the world we have studied from the secondary data. The results of research show the positive influence of ISO 9001 on human resource management in the world practice as in Croatia. The improvements refer on the reduced labor turnover, better communication and cooperation such as the working enthusiasm, higher level of satisfaction, better employee participation in decision making, improved professional skills and knowledge development.

Key words: hotels, world, Croatia, ISO 9001 , human resource management
\end{abstract}

\section{INTRODUCTION}

The International Organization for Standardization has set up standard ISO 9001 as international standard for Quality Management System. The certificate ISO 9001 proves that the company possessing it respects all the international and national quality standards and regularly surveys the quality system that has been incorporated in its business practice. For the purpose of this paper we have stated the following hypothesis:

H1. There is a positive influence of International Standard ISO 9001 implementation on the human resource performances in hotels in the world

H2. Implementation of Quality Management System ISO 9001 improves human resource management performances in Croatian hotel industry.

We have made secondary research for examining influence of ISO 9001 implementation on the human resource management in the world hotel business practice. For testing second hypotheses we have made empirical research. It has been carried out in all the Croatian hotels that have implemented Quality Managing System ISO 9001. We have used method of structural interview with hotel managers. In our research we have also used five-point Likert scale, descriptive statistics and Chi-square testing for analyzing the data.

\section{INFLUENCE OF QUALITY MANAGEMENT SYSTEM ISO 9001 ON HUMAN RESOURCE MNAGEMENT IN HOTELS IN THE WORLD}

According to the Quality Standard ISO 9001, a correctly implemented and completed quality system brings certain internal and external advantages to the company. However, it is necessary to emphasize that the benefit amount is directly proportionate to the success of implementation and commitment of all employees Implementation of Quality Management. Implementation of System ISO 9001 in hotel enterprises increases paperwork, demands time for implementation and causes additional costs. According to the results of research, implementation of ISO 9001 has reduced labour turnover such as losses and improved publicity (Callan, 1992). Walker \& Salameh (1996) report on the positive changes reflected on some operations aspects and in staff turnover, enthusiasm, cooperation, communication and employee satisfaction. Nield \& Kozak (1999) conclude that the implementation of ISO 9001 brings numerous advantages. The improvements in the field operational performances are improved operation systems and reduced costs. The hotels have also improved marketing performances i.e. increased consumer satisfaction, increased competitiveness, higher nation-wide recognition. In the area of human resource management the hotels decreased staff turnover and increased employee satisfaction. Ho et al. (2001) conclude that implementation has direct effect on customer service in terms of error reduction, greater operational reliability and enhanced employee commitments. Susskind et al. (2007) confirm that the implementation of quality system has influence on reducing errors and improves reliability of operations. Alonso-Almeida \& Rodriguez-Anton (2011) found out improvements in the field of reducing errors, less overrall effort to maintain service levels, and reliability of service and operations improvement.

\section{RESULTS OF RESEARH CARRIED OUT IN CROATIAN HOTEL INDUSTRY}

\subsection{Basic research results}

We have studied the experience of all Croatian hotels that have implemented Quality Management System ISO 9001 using the method of structural interview. It included 25 hotels in Croatia. The focus of the empirical research was on top managers. Unfortunately, only 16 hotel managers were willing to take part in the interview. Analyzing the data related to the county it is visible that the largest number of hotels that have implemented ISO 9001 (33\%) are located in the Istria County, followed by the Dubrovačko-Neretvanska County (29\%) and (23\%) in the Primorsko-Goranska County. Only 5\% of the hotels are in the Krapinsko-Goranska County, SisačkoMoslovačka and the Zagreb County. According to the research results, it arises that the awareness level regarding quality improvement is the highest in Istria, followed by the Dubrovnik-Neretva County and the Primorsko-Goranska County. From the data about the number of employees in the Croatian hotels which have implemented Quality Managing System ISO 9001, it arises that the majority employs between 140 and 170 employees (40\%). The share of hotels employing more than 200 persons is represented by the significant figure of $20 \%$. All the managers participating in the research concerning the hotels in the Republic of Croatia which have implemented Implementation of Quality Managing SystemISO 9001 , hold a university degree. Therefore we can conclude that there is a correlation between the education level of hotel 
managers and implementation of Quality Managing System ISO 9001 .

\subsection{Influence of ISO 9001 implementation on human resource management in Croatian hotel industry}

According to the opinion of sixteen hotel managers, employee satisfaction in the Croatian hotels before the implementation of Implementation of Quality Managing System ISO 9001 is medium satisfactory. Rating the employee satisfaction after the implementation of Standard ISO 9001 in the hotels in the Republic of Croatia, five managers rated it as very satisfactory and four managers rated it as medium satisfactory. Given the empirical value $\chi 2=19,2(\alpha=0,05)$, the applied $\chi 2$ test of independence of variable shows that there is a correlation between the implementation of International Standard Implementation of Quality Managing System ISO 9001 and increased employee satisfaction. Assessing employee participation in decision making in the hotels in the Republic of Croatia after the implementation of Quality Management System ISO 9001, all the hotel managers participating in the research rated it as satisfactory. Given the empirical value $\chi 2=32(\alpha=0,05)$, it is obvious that the implementation of Quality Management System ISO 9001 improves staff participation in decision making in Croatian hotels. The communication between different hotel departments influences the quality of integral hotel product. Regardless of the methods used to facilitate the communication, managerial responsiveness to employee concerns represents an important element for the relationship of managers and supervisees. Sixteen interviewees assessing the improvement in communication among the employed in the hotels in Croatia before the implementation of Implementation of Quality Managing System ISO 9001 rated it as medium satisfactory. Assessing this factor after the implementation of Implementation of Quality Managing System ISO 9001, six managers rated it as very satisfactory and four managers as medium satisfactory. Given the empirical value $\chi^{2}=19,2(\alpha$ $=0,05$ ), it shows that there is a correlation between the implementation of Implementation of Quality Managing System ISO 9001 and improved communication among the employed in Croatian hotels. Assessing professional skills development in Croatian hotels after the implementation of Implementation of Quality Managing System ISO 9001, seven managers rated this factor as very satisfactory and nine as satisfactory. Given the calculated empirical value for the above data $\chi^{2}=32(\alpha=0,05)$, the applied $\chi^{2}$ test of independence of variable shows that there is a correlation between the implementation of Implementation of Quality Managing System ISO 9001 and improved professional skills and knowledge development in Croatian hotels. Management System ISO 9001 in hotel enterprises in Croatia increases paperwork, is time demanding and causes additional costs. The process is also somewhat difficult for the hotel staff to accept (Pavlic \& Dragicevic, 2008).

\section{CONCLUSION}

According to the results of research it is visible that there is a correlation between the implementation of Quality Management System ISO 9001 and improving of human resource management performances in hotel business practice in the world, such as in the hotels bussiness practice in Croatia. There is a correlation between the implementation of Quality Management System ISO 9001 and increased employee satisfaction in hotels in the Republic of Croatia, such as correlation between the implementation of Implementation of Quality Managing System ISO 9001 and improved employee communication in hotels in the Republic of Croatia. The increased level of employee satisfaction is extremely important since reflected on the quality of hotel service and client satisfaction. Better communication of the employed in a hotel advances the quality of hotel product and strengthens the linkages among the accommodation department, reception, food and beverage department and all the other hotel departments. The implementation of Implementation of Quality Managing System ISO 9001 implies that all the employees contribute to the increased quality of hotel product and better linkages between hotel departments. When managers are "not in touch" with other employees, they make poor decisions, while the employees show high absenteeism, low commitment and cause conflicts. We would like to point out that implementation of Implementation of Quality Managing System ISO 9001 improves professional skills and knowledge development in Croatian hotels. The latter is important considering the low level of education of the cadre in Croatian hotels, including hotel managers (Avelini Holjevac, 2002, p. 430). The implementation of Quality Managing System ISO 9001 in larger number of Croatian hotels could improve the professional skills and knowledge development in Croatian hotels which are still lagging behind the needs in Croatia. There is a lack of systematic researches in the world, The Quality Management System ISO 9001 has been implemented in small number of hotels in the Republic of Croatia. Both we can consider as a limitation of research.

\section{ACKNOWLEDGEMENTS}

We are grateful to Croatian hotel managers for their help in carrying out the primary research in Croatia.

\section{REFERENCES}

Alonso-Almeida, M \& Rodriguez-Anton, J. (2011). Organisational behaviour and strategies in the adoption of certified management systems: an analysis of the Spain hotel industry, Journal of Cleaner Production, No. 19, No. 13, p. p. 1455-1463., ISSN: 0959-6526

Avelini Holjevac, I. (2002). Upravljanje kvalitetom и turizmu $i$ hotelskoj industriji, (Quality management in tourism and hospitality industry), Fakultet za turistički i hotelski menadžment, (Univesity for tourism and hospitality management), ISBN : 953-6198-29-0, Opatija

Callan, R.J. (1992). The British Standard 5750- A Quality Control Instrument for the Hotel and Catering Industry: The Case Study of Astley Bank, International Journal of Hospitality Management, Vol. 11, No. 4, p.p. 359-372., ISSN: 0278-4319

Callan, R. J. (1992). Quality Control at Avant Hotels: The Debut of BS 5750, Service Industries Journal , Vol. 12, No. 1 , p. p. $17-33$

Ho et al. (2001).Total quality management: an empirical test for mediation effect, International Journal of Production Research, Vol. 39, No. 3, p.p. 529-548, ISNN: 0020-7543

Nield, K. \& M. Kozak, M. (1999). Quality certification in the hospitality industry: analizying the benefits of ISO 9000, Cornell Hotel \& Restaurant Administration Quarterly, Vol. 40 , No. 2 , p.p. $40-45$

Pavlic, I. \& Dragicevic, M., (2008). Implementation of integrated managing systems in the hotel industry of the dubrovnik riviera, Proceedings of 4th International Conference „An Enterprise Odyssey: Tourism-Governance and Enterpreneurship “, Cavtat, ISBN10: 953-6025-248, ISBN 13: 978-953-6025-24-4, p.p. 1874-1882., Faculty of Business Zagreb, Zagreb

Susskind, A. M; Kaemar. M. K. \& Borhgrevink, C. P. How organizational standards and coworker support impove restaurant service, Cornell Hotel \& Restaurant Administration Quarterly, Vol. 48, No. 3 , p.p. 370-384

Walker, J. R. \& Salameh, T.T (1996). The Q.A. Payoff. Cornell Hotel and Restaurant Administration Quarterly, Vol. 37. No. 1, p.p. 57-50. 